\begin{tabular}{l|l|l} 
Jurnal Eksplorasi Akuntansi (JEA) & $\begin{array}{l}\text { e-ISSN : 2656-3649 (Online) } \\
\text { hol. 3, No 4, November 2021, Hal 908-921 }\end{array}$
\end{tabular}

\title{
Pengaruh Karakteristik Dewan Komisaris Terhadap Kemampuan Memprediksi Financial Distress: Studi pada Perusahaan BUMN
}

\author{
Frans Dika Permana ${ }^{1 *}$, Vanica Serly ${ }^{2}$ \\ ${ }^{1,2}$ Fakultas Ekonomi, Universitas Negeri Padang \\ *Korespondensi: fransdikapermana99@gmail.com
}

\begin{abstract}
This research aims to analysis the effect size of board commissioners, independent commissioners, competence of board commissioners and meeting frequency of board commissioners on financial distress. The data in study are annual report of BUMN companies in Indonesian registered at the ministry BUMN in 2015 - 2019. This research using purposive sampling method obtained by 175 sample from 35 companies conducted observations from 2015 - 2019, the hypothesis testing in this research using multiple linear regression analysis. The result of this research showed that the independent commissioners, competence of board commissioners and meeting frequency of board commissioners have significantly positive effect on financial distress.
\end{abstract}

Keywords : Board Of Commissioners; Financial Distress; Good Corporate Governance.

How to cite (APA $6^{\text {th }}$ style)

Permana, F.D \& Serly, V. (2021). Pengaruh Karakteristik Dewan Komisaris terhadap Kemampuan Memprediksi Financial Distress:Studi pada Perusahaan BUMN. Jurnal Eksplorasi Akuntansi (JEA), 3 (4), 908-921.

\section{PENDAHULUAN}

Persaingan bisnis yang ketat saat ini antar perusahaan telah mengarah pada sektor perekonomian yang sedang mengalami perubahan yang sangat cepat. Perusahaan dituntut dapat bersaing dengan perusahaan lain untuk meningkatkan keuntungan perusahaan. Jika perusahaan belum siap menghadapinya maka penjualan perusahaan akan turun, dan selanjutnya akan berdampak terhadap laporan keuangan. Namun, biasanya perusahaan yang akan menghadapi persaingan ekonomi yang tidak siap terhadap kondisi saat ini, akhirnya dipaksa bubar karena masalah financial distress (Damayanti et al., 2017).

Prediksi financial distress merupakan kondisi dimana suatu perusahaan yang sedang mengalami kesulitan keuangan yang berpengaruh terhadap kelangsungan hidup perusahaan seperti risiko kebangkrutan yang biasanya dilakukan oleh pihak internal dan eksternal perusahaan (Loman \& Kunci, 2015). Permulaan kebangkrutan pada perusahaan diawali dengan terjadinya financial distress sampai dinyatakan bahwa perusahaan tersebut pailit. Kebangkrutan kemungkinan masalah dalam perusahaan yang terjadi jika perusahaan dihadapi dalam situasi yang sulit, terdapat dua faktor yang mengarah pada kebangkrutan perusahaan yaitu internal dan eksternal. Pada faktor internal yaitu dari perspektif keuangan perusahaan yang terjadi saat kegagalan perusahaan tidak lagi mampu melunasi semua 
hutang dan memenuhi kewajibannya. Sedangkan pada faktor eksternal yaitu masalah sumber daya perusahaan dan bahan baku, yang membuat perusahaan kehilangan kesempatan dalam produksi dan menghasilkan income (Ilmi et al., 2016), Serta menurut data kementerian BUMN pada tahun 2020 terdapat beberapa BUMN yang diprediksi mengalami financial distress dengan terlilit utang sebesar 1.682 Triliun (Suparjo. R, 2021).

Good Corparate Governance gambaran dari sebuah perusahaan dalam menentukan bagaimana perusahaan mengawasi hak pemegang saham dan menentukan aturan dalam memilih anggota dewan komisaris berdasarkan kemampuan mereka (Mueller, 2018). Good Corporate Governance adalah suatu sistem yang digunakan untuk mengatur hubungan antara berbagai pihak/stakeholders, terutama dalam arti sempit yaitu hubungan dewan komisaris, dewan direksi, dan pemegang saham untuk mencapai tujuan perusahaan (Susetyo \& Ramdani, 2020).

Peraturan Otoritas Jasa Keuangan Nomor 33/POJK.04/2014 pasal 28 tentang tugas, tanggung jawab, dan wewenang menyatakan bahwa dewan komisaris bertanggung jawab untuk mengawasi dan bertanggung jawab atas pengawasan kebijakan Manajemen, kinerja secara keseluruhan emiten atau perusahaan publik pada umumnya dan memberi rekomendasi untuk dewan direksi. Menurut (Saleem et al., 2016) pemegang saham mengandalkan kemampuan dewan komisaris dalam memantau kinerja direksi. Oleh karena itu, tanggung jawab atas kualitas laporan keuangan ada pada efektivitas karakteristik dewan komisaris.

Dewan komisaris adalah salah satu komponen penting dalam Good Corporate Governance (Setiawan, 2018). Dewan komisaris yang dengan kinerja baik dan efisien akan memberikan pengaruh positif terhadap perusahaan. Menurut peraturan Otoritas Jasa Keuangan Nomor 33/POJK.04/2014 pasal 28 menjelaskan bahwa dewan komisaris mempunyai tugas dan tanggung jawab dalam proses pengawasan terhadap kinerja manajemen. Dengan adanya dewan komisaris sebagai salah satu mekanisme penting dalam Good Corporate Governance untuk mencegah terjadinya financial distress yang nantinya akan bertanggung jawab kepada stakeholder sebagai pemilik perusahaan (Huljanna, 2019).

Ukuran dewan komisaris adalah jumlah anggota dewan komisaris, semakin kecil ukuran dewan komisaris maka semakin efektif karena jumlah anggota dewan komisaris yang banyak berdampak pada lamanya proses pengambilan keputusan (Setiawan, 2018). Menurut Peraturan Otoritas Jasa Keuangan Nomor 33/POJK.04/2014 Pasal 20 Nomor 1 bahwa dewan komisaris berjumlah paling sedikit terdiri dari 2 (dua) orang anggota dewan komisaris.

Komisaris independen adalah semua anggota dewan komisaris bekerja secara independen atau tidak berpihak kepada siapa pun, tidak mudah dipengaruhi dan berlaku secara adil terhadap masalah yang dihadapi perusahaan serta komisaris independen berperan penting terhadap pengawasan yang dilakukan oleh dewan komisaris (Setiawan, 2018). Independensi ini bertujuan untuk memberikan pandangan objektif dan integritas dalam pelaporan serta rekomendasi dengan maksud lebih adil dan tidak berpihak terhadap penyelesaian masalah (Forum for Corporate Governance in Indonesia, 2002).

Kompetensi dewan komisaris adalah keterampilan akuntansi dan keuangan (financial expertise) akan menguntungkan dewan komisaris memahami laporan keuangan dan masalah internal laporan keuangan yang lebih baik. Selain itu, dewan komisaris dengan keahlian yang mumpuni dapat memahami dan memecahkan masalah laporan keuangan (Prastiti \& Meiranto, 2013). Menurut (ASEAN Corporate Governance Scorecard, 2017) kompetensi dapat dilihat dari pengalaman dewan komisaris dalam bidang industri yang pernah dijalankan sebelumnya.

Frekuensi pertemuan dewan komisaris berhubungan rapat dewan komisaris adalah hal penting terhadap efektivitas dewan komisaris dalam melaksanakan pengendalian dan pengawasan. Rapat dewan pengawas merupakan media komunikasi dan koordinasi kedua 
belah pihak saat anggota dewan komisaris menjalankan tugasnya pengawas manajemen. Pertemuan tersebut akan membahas arah dan strategi perusahaan, evaluasi kebijakan yang telah diadopsi oleh manajemen, dan penyelesaian konflik kepentingan (Prastiti \& Meiranto, 2013). Frekuensi rapat dewan komisaris yang dilakukan secara teratur dan terkontrol dengan baik mempunyai dampak positif dalam pengawasan serta penyampaian kritik terhadap kebijakan - kebijakan yang diambil manajemen (Zahra et al., 2016).

Berlandaskan hal tersebut penelitian ini mengacu pada fenomena diatas bahwa terdapat tujuh BUMN yang masih mencatatkan kerugian dari tahun 2015 - 2019 walaupun telah banyak dana yang dialokasikan dari Penyertaan Modal Negara (PNM). Maka dari itu penulis tertarik untuk meneliti tentang perusahaan BUMN dikarenakan sebagian besar dari laba BUMN untuk negara yang dapat dirasakan manfaat bagi masyarakat. Perbedaan penelitian ini dengan penelitian sebelumnya adalah penelitian sebelumnya yang dilakukan oleh (Putra \& Serly, 2020) mengkaji tentang pengaruh komite audit terhadap financial distress, pada penelitian tersebut terdapat gap pada variabel independen. Oleh karena penulis tertarik untuk melakukan penelitian selanjutnya berdasarkan latar belakang tersebut, peneliti tertarik untuk melakukan penelitian yang berjudul pengaruh karakteristik dewan komisaris terhadap financial distress pada perusahaan BUMN di Indonesia.

\section{REVIUW LITERATUR DAN HIPOTESIS Agency Theory (Teori Keagenan)}

Teori Agensi menurut (Jensen \& Meckling, 1976) adalah teori menjelaskan hubungan perjanjian antara principal dan agent. Hubungan yang dimaksud adalah komitmen kerja sama yang melibatkan principal (stakeholder) dan agent (manajemen) dalam menjalankan aktivitas operasional perusahaan (Zainuddin, 2019). Stakeholder atau principal merupakan pihak yang memberikan tugas kepada agent atau manajemen yang merupakan pihak yang diberikan tugas dalam menjalakan aktivitas perusahaan serta hubungan ini sering menimbulkan konflik atara kedua pihak yang saling berkepentingan yang disebut masalah keagenan atau agency (Chrissentia \& Syarief, 2018).

Stakeholder merupakan pihak yang memberikan wewenang kepada manajemen, perbedaan asimetri informasi membuat munculnya masalah agensi yang tidak dapat mengawasi setiap saat kinerja dari manajemen. pentingnya pengawasan (monitoring) untuk mencapai tata kelola perusahaan yang baik (Andarini \& Januarti, 2012). Stakeholder dan manajemen akan melakukan usaha untuk dapat meminimalisir biaya yang dikeluarkan dari konflik keagenan, untuk mengawasi kinerja dari manajemen yang tidak bisa dilakukan stakeholder setiap saat, maka stakeholder memberikan wewenang kepada dewan komisaris (Akmyga \& Mita, 2015).

\section{Prediksi Financial Distress}

Financial Distress adalah tahap kemerosotan kondisi keuangan perusahaan sebelum bangkrut, dari gambaran status keuangan perusahaan di dalam laporan keuangan perusahaan. Hal utama yang dapat dilihat dari financial distress adalah ketidakmampuan perusahaan membayar utang jangka pendeknya (Chrissentia \& Syarief, 2018). Menurut (Ardian et al., 2016) Financial Distress merupakan aktivitas operasional perusahaan yang tidak memenuhi kewajibannya dan harus dipenuhi oleh perusahaan. Oleh karena itu, dapat disimpulkan masalahnya adalah arus kas operasi tidak dapat dipenuhi Kewajiban perusahaan saat ini, seperti hutang dagang dan biaya bunga. 


\section{Good Corporate Governance}

Good Corporate Governance merupakan suatu aturan yang berlaku bagi perusahaan untuk mengatur dan mengontrol perusahaan guna menambah nilai bagi pemegangnya saham (Haziro \& Negoro, 2017). Pada saat yang sama, Organization for Economic Cooperation and Development (OECD) mendefinisikan GCG sebagai alat perusahaan guna menetapkan tujuan dan alat dalam mencapai tujuannya serta pengawasan pada perusahaan. Maka disimpulkan, GCG adalah seperangkat hukum atau peraturan wajib yang dilakukan untuk mengatur interaksi dari semua institusi perusahaan, termasuk manajer sampai kepada pemegang saham untuk merealisasikan keuntungan atau peningkatan nilai perusahaan guna menghindari resiko bisnis perusahaan dan resiko saat krisis global (Ferbienti et al., 2018).

\section{Dewan Komisaris}

Berdasarkan Undang-Undang Republik Indonesia Nomor 40 Tahun 2007 tentang Perseroan Terbatas, Dewan komisaris adalah organ perusahaan bertanggung jawab atas pengawasan umum dan/atau khusus anggaran dasar perusahaan dan memberikan rekomendasi kepada direksi. Komisaris bersifat independen, mereka tidak berpartisipasi dalam pengendalian perusahaan dan mampu melaksanakan tugas secara objektif, sematamata untuk kepentingannya perusahaan, terlepas dari pengaruh apapun mungkin bertentangan dengan kepentingan pihak lain. Menurut (Forum for Corporate Governance in Indonesia, 2002), peran dewan komisaris sangat penting di dalam perusahaan, terutama dalam penerapan Good Corporate Governance.

\section{Karakteristik Dewan Komisaris}

Dalam struktur tata kelola perusahaan keberadaan dewan komisaris merupakan faktor penting untuk perbaikan kualitas pengendalian internal perusahaan. Pada dasarnya partisipasi dewan komisaris yang dirancang untuk memberikan perlindungan terbaik kepada stakeholder. Peraturan OJK Nomor 33 tahun 2014 menetapkan aturan mengenai "Pembentukan dan Pedoman Pelaksanaan Kinerja Direksi dan Dewan Komisaris". Berdasarkan aturan tersebut, dewan komisaris wajib dimiliki oleh perusahaan dengan beberapa karakteristik yaitu : 1) ukuran dewan komisaris atau jumlahnya minimal terdiri dari dua orang anggota dewan komisaris dan satu di antaranya komisaris independent, 2) independensi dewan komisaris dilihat dari anggota yang tidak memiliki hubungan dengan manajemen dan berasal dari pihak luar, 3) memiliki kompetensi financial expertise dalam bidang akuntansi dan ekonomi, 4) frekuensi rapat dewan komisaris minimal dua kali dalam setahun yang harus dihadiri oleh seluruh anggota dewan komisaris (Otoritas Jasa Keuangan, 2014).

\section{Ukuran Dewan Komisaris}

Menurut pedoman umum Tata Kelola Perusahaan di Indonesia, jumlah anggota dewan komisaris harus sesuai dengan kompleksitas perusahaan dan fokus pada efektivitas pengambilan keputusan perusahaan. Di perusahaan, jumlah dewan komisaris berbeda-beda, menurut Peraturan OJK Nomor 33 tahun 2014 dewan komisaris paling kurang terdiri dari dua orang. Jumlah dewan komisaris yang besar bisa menguntungkan perusahaan, misalnya dalam pertemuan antar dewan komisaris mungkin ada perbedaan pendapat antara dua pihak tersebut. Jika jumlah anggota dewan kurang dari jumlah anggota direksi dan membuat dewan komisaris mengalami tekanan psikologis. Sebab, jumlah anggota dewan komisaris harus lebih dari atau sama dengan jumlah anggota dewan direksi (Indrayati, 2010). 


\section{Komisaris Independen}

Komisaris independen berperan penting dalam pengawasan dilakukan oleh dewan komisaris. Komisaris independen harus mengawasi secara efektif untuk meminimalkan kesalahan oleh manajemen (Setiawan, 2018). Menurut (Jouber \& Fakhfakh, 2011) pada penelitian di perancis menjelaskan jumlah dewan komisaris yang banyak mempunyai dampak yang baik terhadap perusahaan. Keberadaan dewan komisaris dapat meningkatkan kualitas sistem pengendalian internal (Makhdalena, 2011).

Sesuai ketentuan OJK, jumlah minimal komisaris independen di perseroan publik adalah 30\% dari semua anggota dewan komisaris. Bursa Efek Indonesia (BEI) telah mengeluarkan regulasi untuk standar acuan Good Corporate Governance dalam membentuk dewan komisaris yang efektif, dewan komisaris terdiri dari tidak kurang dari tiga anggota, dan mereka mayoritas independen. Artinya paling sedikit satu komisaris independen dan paling sedikit dua anggota lainnya berasal dari luar perseroan. Tujuan dewan komisaris dari pihak independen di luar perusahaan harus terdiri dari individu - individu yang mandiri dan tidak terlibat dalam tugas untuk pengelolaan harian aktivitas perusahaan serta mempunyai pengalaman yang cukup untuk menjalankan fungsi pengawasan yang efektif (Gunawijaya, 2015).

\section{Kompetensi Dewan Komisaris}

Menurut (Otoritas Jasa Keuangan, 2014) bahwa kompetensi yang dimiliki oleh dewan komisaris mempunyai peran yang sangat penting dalam mencapai kesuksesan sebuah perusahaan. Untuk memperoleh dewan komisaris yang kompeten, perusahaan harus mengetahui informasi mengenai dewan komisaris tersebut serta memiliki kualifikasi tertentu dan pengalaman yang cukup untuk menjadi dewan komisaris tersebut (Octosiva et al., 2018). Dilihat dari kriteria ASEAN Corporate Governance Scorecard, keahlian dewan komisaris didasarkan pada pengalaman dalam industri dan apakah memiliki pengalaman dalam industri tersebut. Pada penelitian sebelumnya belum banyak ditemukan dan mendefenisikan kompetensi serta pengalaman industri pada dewan komisaris tersebut. Latar belakang pendidikan bidang akuntansi dan keuangan sangat penting bagi dewan komisaris. Maka dari itu, kompetensi dewan komisaris yang cukup baik menguntungkan stakeholder dalam menganalisis laporan keuangan sehingga kemampuan dewan komisaris tersebut dapat meminimalisir terjadinya financial distress.

\section{Frekuensi Pertemuan Dewan Komisaris}

Peraturan Otoritas Jasa Keuangan Nomor 33/POJK.04/2014 Pasal 31 menjelaskan bahwa rapat wajib dewan komisaris wajib dilaksanakan paling kurang 1 (satu) kali dalam 2 (dua) bulan dan harus dihadiri mayoritas anggota dewan komisaris, serta dewan komisaris wajib untuk melaksanakan rapat berkala bersama direksi paling kurang 1 (satu) kali dalam 4 (empat) bulan dan kehadiran anggota dewan komisaris pada saat rapat wajib diungkapkan pada laporan tahunan perusahaan public atau emiten.

Efektivitas peran dewan komisaris dalam proses pelaporan keuangan dan pengendalian internal membutuhkan pertemuan rutin serta pertemuan secara teratur dan terorganisir dengan baik dapat membantu dewan komisaris dalam pengawasan serta lebih mampu mengkritik yang berhubungan dengan kebijakan-kebijakan yang dilakukan manajemen (Zahra et al., 2016). Maka dapat disimpulkan, semakin banyak frekuensi rapat yang dilakukan dewan komisaris maka informasi terjadinya financial distress juga akan semakin cepat diketahui. 


\section{Pengaruh Ukuran Dewan Komisaris terhadap Prediksi Financial Distress}

Menurut teori keagenan, dewan komisaris merupakan bagian dari pengendalian internal tertinggi, bertanggung jawab mengontrol perilaku manajemen puncak dan ukuran dewan komisaris dipercaya sebagai dasar dalam pengambilan keputusan yang baik (Prastiti \& Meiranto, 2013). Menurut PJOK Nomor 55/PJOK.04/2015 dewan komisaris perlu membentuk komite audit untuk membantu kinerjanya serta bertanggungjawab kepada dewan komisaris.

Menurut (Saleem et al., 2016) bahwa ukuran dewan komisaris mempunyai peranan penting dalam pengambilan keputusan yang efektif dan mempunyai hubungan dengan kinerja perusahaan. Penelitian yang dilakukan oleh (Saleem et al., 2016) menyatakan bahwa ukuran dewan komisaris dapat mengurangi kesalahpahaman dan masalah terkait pelaporan keuangan serta hal ini mempunyai hubungan karena dapat meminimalisir terjadinya financial distress.

$\mathbf{H}_{1}$ : Ukuran dewan komisaris berpengaruh positif terhadap prediksi financial distress.

\section{Pengaruh Komisaris Independen terhadap Prediksi Financial Distress}

Menurut teori keagenan, diperlukan komisaris independen untuk mengawasi dan mengendalikan perilaku direksi mengenai perilaku oportunistik mereka (Jensen \& Meckling, 1976). Teori Agensi berpendapat bahwa semakin tinggi proporsi komisaris independen maka semakin efektif mereka dapat menjalankan tugasnya mengawasi dan mengontrol perilaku direktur eksekutif. Indenpendensi dewan komisaris yang lebih besar mengarah pada keberadaan perusahaan lebih transparan dan dapat mengurangi asimetri informasi diantara investor (Goh et al., 2014).

Berdasarkan hasil penelitian yang dilakukan oleh (Goh et al., 2014) menyatakan keberadaan komisaris independen mempunyai pengaruh terhadap transparansi perusahaan serta kontrol terhadap manajamen perusahaan yang mempu mengurangi resiko terjadinya financial distress. Hal ini sesuai dengan teori agensi bahwa risiko financial distress dapat ditekan dengan adanya kontrol dan pengendalian terhadap tindakan manajemen.

$\mathbf{H}_{2}$ : Komisaris Independen berpengaruh positif terhadap prediksi financial distress.

\section{Pengaruh Kompetensi Dewan Komisaris terhadap Prediksi Financial Distress}

Menurut teori keagenan, untuk menimalisir terjadinya perbedaan informasi antara stakeholder dan manajemen maka penting adanya dewan komisaris sebagai fungsi pengawasan yang sudah memiliki legalitas dan keilmuan melalui jenjang pendidikan serta pengalaman kerja yang sud ah digeluti (Gunawijaya, 2015).

Fungsi dewan komisaris adalah sebagai pengawas dan penasehat tetapi tidak akan bertindak sebagai pengambil keputusan operasional karena pengambilan keputusan operasional adalah tanggung jawab direksi. Dewan komisaris diharapkan memiliki latar belakang akuntansi dan keuangan dengan demikian efektivitas fungsi pengawasan dapat lebih ditingkatkan (Prastiti \& Meiranto, 2013). Penelitian yang dilakukan oleh (Octosiva et al., 2018) bahwa dewan komisaris dengan tingkat keahlian yang tinggi dapat meningkatkan kinerja keuangan pada perusahaan serta dapat meminimalkan risiko terjadinya financial distress.

$\mathbf{H}_{3}$ : Kompetensi dewan komisaris berpengaruh positif terhadap prediksi financial distress.

\section{Pengaruh Frekuensi Pertemuan Dewan Komisaris terhadap Prediksi Financial Distress}

Rapat dewan komisaris adalah hal penting dalam melakukan pengendalian dan pengawasan. Rapat dewan komisaris merupakan wadah komunikasi dan koordinasi kedua belah pihak dalam menjalankan tugasnya mengawasi manajemen. Pada pertemuan tersebut membahas arah dan strategi perusahaan, evaluasi kebijakan yang telah diadopsi oleh manajemen, dan menyelesaikan konflik kepentingan (Prastiti \& Meiranto, 2013). Penelitian yang dilakukan 
oleh (Zahra et al., 2016), pertemuan rutin yang dilakukan dewan komisaris dapat meningkatkan efektifvitas serta peran pengawasan atas proses pelaporan keuangan dan pengendalian internal.

Dari pandangan teori keagenan bahwa jumlah pertemuan dapat dijadikan dasar sebagai proksi waktu yang digunakan dewan komisaris dalam melaksanakan tugas dan monitoring terhadap persiapan pelaporan yang dapat meminimalkan (Zahra et al., 2016)risiko terjadinya financial distress pada perusahaan. Berbeda dengan hasil penelitian yang dilakukan oleh (Zahra et al., 2016) menyatakan tidak terdapatnya pengaruh frekuensi rapat dewan komisaris karena pada pertemuan rutin hanya dijadikan sebagai formalitas tidak membahas secara detail.

$\mathbf{H}_{4}$ : Frekuensi pertemuan dewan komisaris positif berpengaruh terhadap prediksi financial distress.

\section{METODE PENELITIAN}

\section{Sampel dan Jenis Penelitian}

Jenis penelitian ini adalah penelitian asosiatif kasual yang menggunakan metode kuantitatif. Menurut (Sugiyono, 2019), penelitian tersebut didasarkan pada penelitian filsafat positivisme yang bertujuan untuk menganalisis populasi atau sampel tertentu. Dengan instrumen penelitian dan analisis data untuk pengumpulan data yang bersifat statistik untuk menguji hipotesis tertentu. Jumlah sampel dalam penelitian ini adalah 175 dalam lima (5) tahun pengamatan dengan metode purposive sampling sebagai metode pengambilan sampel berdasarkan kriteria tertentu.

Tabel 1

Kriteria Pemilihan Sampel

\begin{tabular}{clc}
\hline No. & \multicolumn{1}{c}{ Kriteria } & Jumlah Perusahaan \\
\hline 1 & $\begin{array}{l}\text { Perusahaan BUMN di Indonesia tahun 2015 - 2019 yang } \\
\text { terdaftar di Kementrian BUMN. }\end{array}$ & 115 \\
2 & $\begin{array}{l}\text { Perusahaan BUMN yang memiliki laporan tahunan (annual } \\
\text { report) dan terdapat data keuangan lengkap berturut - turut dari } \\
\text { tahun 2015 - 2019. }\end{array}$ & (64) \\
Perusahaan BUMN yang memiliki data terkait mengenai \\
penelitian ini, seperti besarnya ukuran dewan komisaris, komisaris \\
independen, kompetensi dewan komisaris, frekuensi pertemuan \\
dewan komisaris, dan data lainnya yang diperlukan untuk \\
mendeteksi keterkaitan dengan kesulitan keuangan (financial \\
distress).
\end{tabular}

\section{Jenis, Sumber dan Teknik Pengumpulan Data}

Jenis data yang digunakan dalam penelitian ini adalah data sekunder. Data sekunder adalah data yang sudah dipubilikasikan pada publik melalui lembaga resmi yang sudah ditetapkan. Sumber data pada penelitian ini adalah laporan tahunan perusahaan BUMN di Indonesia pada tahun 2015 - 2019. Data tersebut diperoleh melalui situs resmi Kementerian BUMN Indonesia yaitu http://bumn.go.id. 


\section{Variabel Penelitian dan Pengukuran}

Variabel dependen dalam penelitian ini adalah prediksi Financial Distress, Pengukuran pada variabel Financial Distress ini mengacu pada penelitian yang dilakukan oleh (Hantono, 2019). Pada model Grover ini nilai cut off yang berlaku adalah $\leq-0,02$ dan $\geq$ 0,01 , jika perusahaan memiliki nilai cut off yang kecil atau sama dengan $-0,02$ maka akan mengalami financial distress sedangkan nilai cut off yang besar atau sama dengan 0,01 diprediksi tidak akan mengalami financial distress. Variabel independen pertama adalah ukuran dewan komisaris yang diukur dengan melihat jumlah anggota dewan komisaris di dalam perusahaan. Variabel independen kedua adalah Independensi dewan komisaris yang diukur dengan indikator persentase (\%) anggota komisaris independen dibandingkan dengan jumlah semua anggota dewan komisaris. Variabel independen ketiga adalah kompetensi dewan komisaris yang diukur dengan cara mencari persentase jumlah anggota dewan komisaris yang memiliki keahlian keuangan terhadap jumlah total anggota dewan komisaris. Variabel independen keempat adalah frekuensi pertemuan dewan komisaris yang diukur dengan melihat jumlah pertemuan yang dilakukan oleh dewan komisaris selama periode tahun berjalan (Prastiti \& Meiranto, 2013).

\section{Metode Analisis Data}

Analisis data yang digunakan dalam penelitian ini adalah analisis pada program SPSS yaitu analisis regresi linier berganda yang mengacu pada penelitian (Masak \& Noviyanti, 2019). Analisis ini digunakan menganalisis variabel independen atau variabel X (ukuran dewan komisaris, Independensi dewan komisaris, kompetensi dewan komisaris, dan frekuensi rapat dewan komisaris) terhadap variabel dependen atau variabel $\mathrm{Y}$ (Financial Distress) memiliki model sebagai berikut:

$$
\mathrm{Y}=\alpha+\beta 1 \mathrm{X} 1+\beta 2 \mathrm{X} 2+\beta 3 \mathrm{X} 3+\beta 4 \mathrm{X} 4+\mathrm{e}
$$

\section{HASIL DAN PEMBAHASAN \\ Model Regresi Berganda}

\section{Tabel 2 \\ Hasil Regresi}

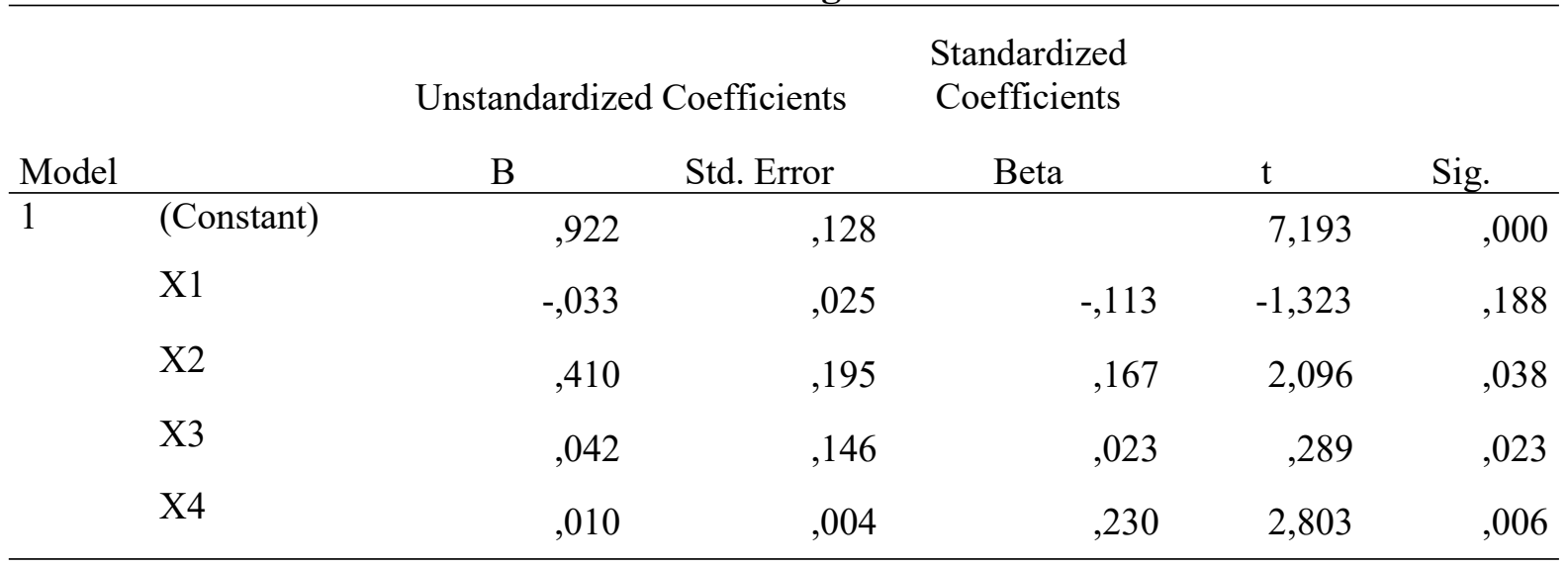

a. Dependent Variable: Y

Model regresi linier berganda yang didapatkan berdasarkan tabel diatas dengan model sebagai berikut :

$$
\mathrm{Y}=1,193-0,033 \times 1+0,410 \times 2+0,042 \times 3+0,010 X 4+e
$$

Dari model di atas dapat diinterpretasikan nilai koefisien $\beta 1$ adalah negatif sebesar 0,033 
menunjukkan bahwa setiap bertambahnya variabel Ukuran Dewan Komisaris $\left(\mathrm{X}_{1}\right) 1$ satuan akan menurunkan financial distress sebesar 3,3\%. Ini memiliki makna, apabila ukuran dewan komisaris meningkat maka financial distress menurun. Nilai koefisen $\beta 2$ adalah positif sebesar 0,410 menunjukkan bahwa variabel Komisaris Independen $\left(\mathrm{X}_{2}\right)$ terjadi penambahan 1 satuan dewan komisaris independen maka akan meningkatkan financial distress sebesar 41\%. Ini memiliki makna, apabila komisaris independen meningkat maka financial distress akan meningkat juga. Nilai koefisien $\beta 3$ adalah positif sebesar 0,042 menjelaskan bahwa variabel Kompetensi Dewan Komisaris $\left(\mathrm{X}_{3}\right)$ bertambah 1 satuan maka akan meningkatkan financial distress sebesar 4,2\%. Ini memiliki makna kompetensi dewan komisaris meningkat maka akan meningkatkan financial distress. Nilai koefisien $\beta 4$ adalah positif sebesar 0,010 menunjukkan bahwa apabila variabel Frekuensi Pertemuan Dewan Komisaris $\left(\mathrm{X}_{4}\right)$ meningkat 1 satuan maka akan meningkatkan financial distress sebesar 1\%. Ini bermakna bahwa apabila frekuensi pertemuan dewan komisaris meningkat maka financial distress akan meningkat juga.

Uji Kelayakan Model

Uji Koefisien Determinasi (Adjusted R²)

Tabel 3.

Uji Koefisien Determinasi (Adjusted R $\mathbf{R}^{2}$ )

\begin{tabular}{llrrrr}
\hline Model & R & R Square & \multicolumn{1}{c}{ Adjusted R Square } & \multicolumn{1}{c}{ Std. Error of the Estimate } & Durbin-Watson \\
\hline 1 &, $379^{\mathrm{a}}$ &, 144 &, 123 &, 42580 &, 632
\end{tabular}

a. Predictors: (Constant), x4, x2, x3, x1

b. Dependent Variable: Y

Berdasarkan tabel di atas nilai dari R2 sebesar 0,144 memiliki makna bahwa 14,4\% prediksi financial distress dapat dijelaskan oleh variabel Ukuran Dewan Komisaris $\left(\mathrm{X}_{1}\right)$, Komisaris Independen $\left(\mathrm{X}_{2}\right)$, Kompetensi Dewan Komisaris $\left(\mathrm{X}_{3}\right)$, dan Frekuensi Pertemuan Dewan Komisaris $\left(\mathrm{X}_{4}\right)$.S Sisanya sebesar $85,6 \%$ ditentukan oleh variabel lain yang tidak dimasukkan dalam model.

Uji Simultan F

Tabel 4

Uji Simultan F

\begin{tabular}{llrrrrr}
\hline & Model & Sum of Squares & df & Mean Square & F & \multicolumn{1}{c}{ Sig. } \\
\hline 1 & Regression & 5,076 & 4 & 1,269 & 7,000 &, $000^{\text {b }}$ \\
Residual & 30,278 & 167 &, 181 & & \\
Total & 35,354 & 171 & & &
\end{tabular}

a. Dependent Variable: Y

b. Predictors: (Constant), x4, x2, x3, x1 
Berdasarkan pada tabel diatas dengan menggunakan tingkat signifikansi 0,05 ( $\alpha=5 \%)$ dapat disimpulkan variabel Ukuran Dewan Komisaris $\left(\mathrm{X}_{1}\right)$, Komisaris Independen $\left(\mathrm{X}_{2}\right)$, Kompetensi Dewan Komisaris $\left(\mathrm{X}_{3}\right)$ dan Frekuensi Pertemuan Dewan Komisaris $\left(\mathrm{X}_{4}\right)$ berpengaruh terhadap prediksi financial distress karena nilai Sig. lebih kecil dari 0,05 yaitu sebesar 0,000 ..

Berdasarkan Tabel 2 didapatkan nilai Sig dari variabel Ukuran Dewan Komisaris $\left(\mathrm{X}_{1}\right)$ sebesar $0,188 \geq$ alpha $(0,05)$. Maka dapat dikatakan bahwa variabel Ukuran Dewan Komisaris $\left(\mathrm{X}_{1}\right)$ tidak berpengaruh terhadap prediksi financial distress secara signifikan. Nilai Sig dari variabel Komisaris Independen $\left(\mathrm{X}_{2}\right)$ sebesar $0,038 \leq$ alpha $(0,05)$. Maka dapat dikatakan bahwa variabel Komisaris Independen $\left(\mathrm{X}_{2}\right)$ berpengaruh terhadap prediksi financial distress secara signifikan.

Nilai signifikan dari variabel Kompetensi Dewan Komisaris $\left(\mathrm{X}_{3}\right)$ sebesar $0,023 \leq$ dari alpha $(0,05)$. Maka dapat dikatakan bahwa variabel Kompetensi Dewan Komisaris $\left(\mathrm{X}_{3}\right)$ berpengaruh terhadap prediksi financial distress secara signifikan. Nilai Sig dari variabel Frekuensi Pertemuan Dewan Komisaris $\left(\mathrm{X}_{4}\right)$ sebesar $0,006 \leq$ alpha $(0,05)$. Maka dapat dikatakan bahwa variabel Frekuensi Pertemuan Dewan Komisaris $\left(\mathrm{X}_{4}\right)$ berpengaruh terhadap prediksi financial distress secara signifikan. Hasil hipotesis bisa dilihat pada Tabel 5.

\section{Tabel 5}

\section{Hasil Pengujian Hipotesis}

\begin{tabular}{clcc}
\hline No. & Variabel & Hipotesis & $\begin{array}{c}\text { Pengujian } \\
\text { Hipotesis }\end{array}$ \\
\hline 1. & Ukuran Dewan Komisaris & Berpengaruh & Ditolak \\
2. & Komisaris Independen & Berpengaruh & Diterima \\
3. & Kompetensi Dewan Komisaris & Berpengaruh & Diterima \\
4. & Kompetensi Dewan Komisaris & Berpengaruh & Diterima \\
\hline
\end{tabular}

Merupakan pengujian yang dilakukan untuk melihat apakah terdapat pengaruh atau tidak nya variabel independen (Ukuran Dewan Komisaris, Komisaris Independen, Kompetensi Dewan Komisaris, dan Frekuensi Pertemuan Dewan Komisaris terhadap variabel dependen (Prediksi Financial Distress).

\section{Pembahasan}

\section{Pengaruh Ukuran Dewan Komisaris terhadap Prediksi Financial Distress}

Berdasarkan hasil pengujian pada variabel Ukuran Dewan Komisaris memperlihatkan bahwa variabel ini tidak memiliki pengaruh terhadap financial distress. Dengan demikian hipotesis $1\left(\mathrm{H}_{1}\right)$ ditolak yang menyatakan Ukuran Dewan Komisaris berpengaruh positif terhadap financial destress. Hal ini menunjukan bahwa semakin banyak anggota dewan komisaris suatu perusahaan maka akan semakin meningkatkan kemungkinan terjadinya financial distress.

Sejalan dengan penelitian yang dilakukan (Setiawan, 2018) menjelaska ukuran dewan komisaris adalah jumlah anggota dewan komisaris, semakin kecil ukuran dewan komisaris maka semakin efektif karena jumlah anggota dewan komisaris yang banyak berdampak pada lamanya proses pengambilan keputusan. 


\section{Pengaruh Komisaris Independen terhadap Prediksi Financial Distress}

Berdasarkan pengujian pada variabel Independensi Dewan Komisaris memperlihatkan bahwa variabel ini memiliki pengaruh positif terhadap financial distress. Dengan demikian hipotesis $2\left(\mathrm{H}_{2}\right)$ diterima yang menyatakan Independensi Dewan Komisaris berpengaruh positif terhadap financial distress. Hal ini menunjukan bahwa semakin tingginya independensi maka akan berkurangnya kemungkinan financial distress didalam suatu perusahaan.

Menurut teori keagenan, diperlukan komisaris independen untuk mengawasi dan mengendalikan perilaku direksi mengenai perilaku oportunistik mereka (Jensen \& Meckling, 1976). Teori Agensi berpendapat bahwa semakin tinggi proporsi komisaris independen maka semakin efektif mereka dapat menjalankan tugasnya mengawasi dan mengontrol perilaku direktur eksekutif. Indenpendensi dewan komisaris yang lebih besar mengarah pada keberadaan perusahaan lebih transparan dan dapat mengurangi asimetri informasi diantara investor (Goh et al., 2014).

\section{Pengaruh Kompetensi Dewan Komisaris terhadap Prediksi Financial Distress}

Berdasarkan pengujian hipotesis pada variabel Kompetensi Dewan Komisaris memperlihatkan bahwa variabel ini memiliki pengaruh terhadap financial distress. Dengan demikian hipotesis $3\left(\mathrm{H}_{3}\right)$ diterima yang menyatakan Kompetensi Dewan Komisaris berpengaruh positif terhadap financial distress. Hal ini menunjukan bahwa latar belakang pendidikan dan banyaknya pengalaman anggota dewan komisaris dapat meminimalisir terjadinya financial distress.

Menurut (Otoritas Jasa Keuangan, 2014) bahwa kompetensi yang dimiliki oleh dewan komisaris mempunyai peran yang sangat penting dalam mencapai kesuksesan sebuah perusahaan. Kompetensi dapat dilihat dari pengalaman dewan komisaris dalam bidang industri yang pernah dijalankan sebelumnya (ASEAN Corporate Governance Scorecard, 2017). Hasil yang sama pada penelitian yang dilakukan oleh (Prastiti \& Meiranto, 2013) dan (Octosiva et al., 2018) menemukan bahwa kompetensi pada dewan komisaris mempunyai pengaruh yang signifikan terhadap pengawasan yang dilakukan oleh dewan komisaris yang berdampak pada kinerja keuangan dan pelaporan yang dilakukan manajemen dikarenakan keahlian akuntansi pada dewan komisaris dapat mengatasi, menganalisis, dan memahami masalah yang timbul dalam laporan keuangan.

\section{Pengaruh Frekuensi Pertemuan Dewan Komisaris terhadap Prediksi Financial Distress}

Berdasarkan hasil pengujian pada variabel Frekuensi Pertemuan Dewan Komisaris memperlihatkan bahwa variabel ini tidak memiliki pengaruh terhadap financial distress. Dengan demikian hipotesis $4\left(\mathrm{H}_{4}\right)$ diterima yang menyatakan Frekuensi Pertemuan Dewan Komisaris berpengaruh positif terhadap financial distress. Hal ini menjelaskan bahwa banyak atau sedikitnya pertemuan/rapat yang diadakan maka akan mengurangi kemungkinan terjadinya financial distress.

Berbeda dengan hasil penelitian yang dilakukan oleh (Zahra et al., 2016), menyatakan tidak terdapatnya pengaruh signifikan pada frekuensi rapat dewan komisaris karena pada pertemuan rutin hanya dijadikan sebagai formalitas tidak membahas secara detail. Namun penelitian lain yang ditemukan oleh (Prastiti \& Meiranto, 2013) menjelaskan pertemuan yang dilakukan dewan komisaris dapat meminimalisir terjadinya kecurangan, hal tersebut dikarenakan pada pertemuan rutin memungkinkan dewan komisaris untuk menyelesaikan dan mengidentifikasi masalah potensial terkait dengan pelaporan keuangan serta pencegahan terhadap financial distress. 


\section{SIMPULAN, KETERBATASAN, DAN SARAN \\ Kesimpulan}

Setelah dilakukan analisis data dengan menggunakan regresi linear berganda maka dapat disimpulkan sebagai berikut :

1. Ukuran Dewan Komisaris $\left(\mathrm{X}_{1}\right)$ tidak memiliki pengaruh terhadap Prediksi Financial Distress (Y) pada perusahaan BUMN di Indonesia tahun 2015 - 2019.

2. Komisaris Independen $\left(\mathrm{X}_{2}\right)$ memiliki pengaruh terhadap Prediksi Financial Distress $(\mathrm{Y})$ pada perusahaan BUMN di Indonesia tahun 2015 - 2019.

3. Kompetensi Dewan Komisaris $\left(\mathrm{X}_{3}\right)$ memiliki pengaruh terhadap Prediksi Financial Distress (Y) pada perusahaan BUMN di Indonesia tahun 2015 - 2019.

4. Frekuensi Pertemuan Dewan Komisaris $\left(\mathrm{X}_{4}\right)$ memiliki pengaruh terhadap Prediksi Financial Distress (Y) pada perusahaan BUMN di Indonesia tahun 2015 - 2019.

5. Berdasarkan hasil penelitian dapat disimpulkan pada perusahaan BUMN seharusnya memiliki dewan komisaris yang berkompeten dalam bidangnya dan lebih meningkatkan independensi dewan komisaris yang terlepas dari rangkap jabatan untuk menghindari adanya konflik kepentingan serta intervensi terhadap ke Independenan tersebut. Namun disisi lain frekuensi pertemuan yang dilakukan dewan komisaris harus efektif dan optimal, maka dari itu perlu adanya kompetensi yang mumpuni serta independensi untuk menjaga kelangsungan perusahaan dan mencegah financial distress.

\section{Keterbatasan}

1. Tahun penelitian hanya sampai tahun 2019 sedangkan ada beberapa perusahaan sudah memiliki annual report tahun 2020.

2. Sampel pada penelitian ini hanya pada perusahaan BUMN, sedangkan banyak perusahaan swasta atau sektor lainnya.

3. Penelitian ini hanya fokus pada variabel Good Corporate Governance dan financial distress.

\section{Saran}

Berdasarkan keterbatasan yang telah dijelaskan sebelumnya, peneliti mempunyai saran agar pada penelitian selanjutnya diharapkan dapat mengembangankan penelitian ini.

Adapun saran - saran lainnya yaitu :

1. Pada penelitian selanjutnya diharapkan dapat menambah tahun penelitian sampai tahun 2020 atau tahun terbaru annual report diterbitkan perusahaan.

2. Pada penelitian selanjutnya diharapkan mencoba untuk meneliti sektor lain seperti pertambangan, manufaktur, dan perbankan serta sektor lain yang ada di Bursa Efek Indonesia (BEI).

3. Pada penelitian selanjutnya diharapkan dapat meneliti variabel lain seperti, karakteristik dewan direksi, remunerasi dewan komisaris, political connection dewan komisaris atau direksi

\section{DAFTAR PUSTAKA}

Akmyga, S. F., \& Mita, A. F. (2015). Pengaruh Struktur Corporate Governance Dan Kualitas Audit Terhadap Luas Pengungkapan Kompensasi Manajemen Kunci Di Laporan Keuangan. Jurnal Akuntansi Dan Keuangan Indonesia, 11(1), 19-36. https://doi.org/10.21002/jaki.2015.02

Andarini, P., \& Januarti, I. (2012). Hubungan Karakteristik Dewan Komisaris Dan Perusahaan Terhadap Keberadaan Komite Manajemen Risiko Pada Perusahaan Go Public Indonesia. Jurnal Akuntansi Dan Keuangan Indonesia, 9(1), 83-99. https://doi.org/10.21002/jaki.2012.06 
Ardian, andre vici, Andini, R., \& Raharjo, K. (2016). Pengaruh Rasio Likuiditas, Rasio Leverage, Rasio Aktivitas dan Rasio Profitabilitas Terhadap Financial Distress (pada perusahaan manufaktur yang terdaftar di Bursa Efek Indonesia periode tahun 20132015). Jurnal Ekonimika Bisnis. https://doi.org/10.20594/religionandsociety.21.0_162

ASEAN Corporate Governance Scorecard. (2017). 1(May), 13-14.

Chrissentia, T., \& Syarief, J. (2018). Analisis Pengaruh Rasio Profitabilitas, Leverage, Likuiditas, Firm Age, Dan Kepemilikan Institusional Terhadap Financial Distress. Simak, 16(01), 45-62. https://doi.org/10.35129/simak.v16i01.11

Damayanti, L. D., Yuniarta, G. A., \& Sinarwati, N. K. (2017). Analisis pengaruh kinerja keuangan, Ukuran komite audit dan kepemilikan manajerial terhadap prediksi financial distress (Studi Pada Perusahaan Manufaktur Yang Terdaftar di Bursa Efek Indonesia Periode 2011-2015). JIMAT Undiksha, https://ejournal.undiksha.ac.id/index.php/S1ak/article/viewFile/9675/6147

Ferbienti, F., Indra, Z. A., \& Nauli, P. (2018). Pengaruh Struktur Dewan Komisaris, Kepemilikan Institusional, dan Karakteristik Komite Audit terhadap Financial Distress. The JournalofAccountingandFinanc E, 23(2), 187-200.

Forum for Corporate Governance in Indonesia. (2002). Peranan Dewan Komisaris dan Komite Audit dalam Pelaksanaan Corporate Governance (Tata Kelola Perusahaan). II, $1-36$.

Goh, B. W., Lee, J., Ng, J., \& Ow Yong, K. (2014). The Effect of Board Independence on Information Asymmetry. European Accounting Review, 25(1), 155-182. https://doi.org/10.1080/09638180.2014.990477

Gunawijaya, I. N. A. (2015). Pengaruh Karakteristik Komite Audit, Independensi Dewan Komisaris, Reputasi Auditor Terhadap Financial Distress. Jurnal Akuntansi Bisnis, 2015(27), 1-239.

Hantono, . (2019). Memprediksi Financial Distress Dengan Menggunakan Model Altman Score, Grover Score, Zmijewski Score (Studi Kasus Pada Perusahaan Perbankan). Going Concern: Jurnal Riset Akuntansi, 9(1), 1-12. https://doi.org/10.32400/gc.14.1.22372.2019

Haziro, A. L., \& Negoro, N. (2017). Pengaruh Karakteristik Komite Audit Terhadap Financial Distress Perbankan Indonesia. Jurnal Sains Dan Seni ITS, 6(1), 32-36.

Huljanna, M. (2019). Pengaruh Efektivitas Komite Audit Terhadap Financial Distress (Studi Pada Perusahaan Manufaktur Yang Terdaftar Di Bursa Efek Indonesia Periode Tahun 2014 -2017). In skripsi, 1-65.

Idris, M., \& Kompas.com. (2019). Daftar 7 BUMN yang Tetap Rugi Meski Sudah Disuntik $P M N$.

Www.Kompas.Com. https://money.kompas.com/read/2019/12/21/142657926/daftar-7-bumn-yang-tetap-rugimeski-sudah-disuntik-pmn

Ilmi, A. B., Norita, \& Firli, A. (2016). Analisis Financial Distress dengan Menggunakan Metode Altman, Ohlson, dan Fulmer untuk Memprediksi Kebangkrutan Serta Kesesuaian dengan Opini Auditor (Studi pada Perusahaan Sektor Pertambangan Batu Bara yang Terdaftar di Bursa Efek Indonesia Tahun 2009-20. Sosiohumanitas, 18(2), 11-30.

Indrayati, M. R. (2010). Pengaruh karakteristik dewan komisaris terhadap tingkat konservatisme akuntansi. In Skripsi.

Jensen, michael c, \& Meckling, william h. (1976). Theory Of The Firm: Managerial Behavior, Agency Costs and Ownership Structure. Journal of Financial Economics, 3, 305-360. https://doi.org/10.1177/0018726718812602

Jouber, H., \& Fakhfakh, H. (2011). Earnings management and board oversight: An international comparison. Managerial Auditing Journal, 27(1), 66-86. 
https://doi.org/10.1108/02686901211186108

Makhdalena. (2011). Pengaruh Proporsi Komisaris Independen dan Komposisi Komite Audit Terhadap Internal Control. Jurnal Akuntansi Dan Investasi, 12(1), 1-14.

Masak, F., \& Noviyanti, S. (2019). Pengaruh Karakteristik Komite Audit terhadap Financial Distress. International Journal of Social Science and Business, 3(3), 237. https://doi.org/10.23887/ijssb.v3i3.21002

Mueller, D. C. (2018). Corporate Governance and Neoclassical Economics. International Journal of the Economics of Business, 25(1), 47-64. https://doi.org/10.1080/13571516.2017.1374038

Octosiva, F., Theresia, M., \& Hidayat, A. A. (2018). Pengaruh Independensi, Kompetensi, Dan Partisipasi Dewan Komisaris Terhadap Kinerja Keuangan Perusahaan. Studi Akuntansi Dan Keuangan Indonesia, 1(2), 158-203. https://doi.org/10.21632/saki.1.2.158-203

Otoritas Jasa Keuangan. (2014). Peraturan Otoritas Jasa Keuangan Nomor 33/ POJK. 04/2014. Ojk.Go.Id, 1-21.

Prastiti, A., \& Meiranto, W. (2013). Pengaruh Karakteristik Dewan Komisaris dan Komite Audit Terhadap Manajemen Laba. 2, 1-12.

Putra, R., \& Serly, V. (2020). Pengaruh Karakteristik Komite Audit dan Ukuran Perusahaan Terhadap Financial Distress (Studi Empiris Pada Perusahaan BUMN Di Indonesia Tahun 2014 - 2018). Jurnal Eksplorasi Akuntansi, 2(3), 3160-3178. http://jea.ppj.unp.ac.id/index.php/jea/issue/view/27

Saleem, F., Alifiah, M. N., \& Tahir, M. S. (2016). The effectiveness of monitoring mechanisms for constraining earnings management: A literature survey for a conceptual framework. International Journal of Economics and Financial Issues, 6(3), 209-214.

Setiawan, D. (2018). Karakteristik dewan komisaris dan manajemen laba: bukti pada peristiwa penawaran saham perdana. Jurnal Siasat Bisnis, 22(2), 164-181. https://doi.org/10.20885/jsb.vol22.iss2.art4

Sugiyono, P. D. (2019). Metodologi penelitian kuantitatif kualitatif dan R\&D (2nd ed.). Alfabeta.

Susetyo, D. P., \& Ramdani, S. H. (2020). Pengaruh Good Corporate Governance Terhadap Kinerja Keuangan Perusahaan pada PT.Bank Mandiri Persero,Tbk. Jurnal Ekonomedia, $9(1), 38-51$.

Zahra, F., Pratomo, D., \& Dillak, V. (2016). Pengaruh Komisaris Independen, Ukuran Dewan Komisaris, dan Frekuensi Rapat Dewan Komisaris Terhadap Profitabilitas. EProceeding of Management, 3(3), 3324.

Zainuddin, aisyah ulfah. (2019). Pengaruh efektivitas komite audit terhadap financial distress (Studi Empiris Pada Perusahaan Manufaktur yang Tercatat di Bursa Efek Indonesia Tahun 2015-2018). In Skripsi. 